Published in: Fütterer, D K, Damaske, D, Kleinschmidt, G, Miller, H \& Tessensohn, F (eds.), Antarctica: contributions to global earth sciences, Springer, Berlin, Heidelberg, New York, 45-54 http://dx.doi.org/10.1007/3-540-32934-X

The original publication is available at http://www.springerlink.com see

http://dx.doi.org/10.1007/3-540-32934-X 57

Data are available at: http://dx.doi.org/10.1594/PANGAEA.605211

\title{
Limnology and Sedimentary Record of Radok Lake, Amery Oasis, East Antarctica
}

\author{
Bernd Wagner ${ }^{1} \&$ Holger Cremer ${ }^{2}$ \\ ${ }^{1}$ University of Leipzig, Institute for Geophysics and Geology, Talstraße 35, 04103 Leipzig, Germany, \\ <wagnerb@rz.uni-leipzig.de> \\ ${ }^{2}$ Utrecht University, Department of Palaeoecology, Laboratory of Palaeobotany and Palynology, Budapestlaan \\ 4, 3584 CD Utrecht, The Netherlands Present address: Netherlands Organization of Applied Scientific \\ Research TNO, Core area Built Environment and Geosciences, Geological Survey of the Netherlands, \\ Princetonlaan 6, 3584 CB Utrecht, The Netherlands, <holger.cremer@tno.nl>
}

\begin{abstract}
Radok Lake in Amery Oasis, East Antarctica, has a water depth of ca. 360 m, making it the deepest non-subglacial lake in Antarctica. Limnological analyses revealed that the lake had, despite a $3 \mathrm{~m}$ thick ice cover, a completely mixed water column during austral summer 2001/2002. High oxygen contents, low ion concentrations, and lack of planktonic diatoms throughout the water column indicate that Radok Lake is ultraoligotrophic today.The late glacial and postglacial lake history is documented in a succession of glacial, glaciolimnic, and limnic sediments at different locations in the lake basin. The sediments record regional differences and past changes in allochthonous sediment supply and lake productivity. However, the lack of age control on these changes, due to extensive sediment redeposition and the lack of applicable dating methods, excluded Radok Lake sediments for advanced paleoenvironmental reconstructions.
\end{abstract}

Introduction

Freshwater lake environments in Antarctica react quickly to climatic and environmental changes (Quayle et al. 2002; Spaulding and McKnight 1999). Due to their ability to respond rapidly, lake sediments have been used successfully to reconstruct climatic and environmental changes in the Antarctic ice free regions, the so-called oases (e.g., Doran et al. 1994; Melles et al. 1997; Hendy 2000; Roberts et al. 2001). In East Antarctica, Amery Oasis is one of the largest ice-free regions that hosts lakes of different size and depth. Its remote location,however, has hampered detailed limnological and sedimentological investigations so far.

Radok Lake $\left(70^{\circ} 52^{\prime} \mathrm{S}, 067^{\circ} 58^{\prime} \mathrm{E}\right.$ ), located in Amery Oasis (Fig. 8.6-1), is known to be the deepest nonsubglacial lake in Antarctica. Measurements of the water depth by leadline revealed a minimum water depth of ca. $360 \mathrm{~m}$ (Wand et al. 1987; Wagner 2003). The lake is located at an elevation of $7 \mathrm{~m}$ a.s.l. in an overdeepened basin whose cliffs and steep slopes rise up to $400 \mathrm{~m}$ above the lake. Radok Lake is ca. $10 \mathrm{~km}$ long and up to 3 $\mathrm{km}$ wide. The northern part of the lake is split into two branches (Fig. 8.6-1). At the southwestern corner Battye Glacier enters Radok Lake forming a floating ice tongue. Meltwater supply from the glacier, the melt stream from Glossopteris Gully (Adamson et al. 1997) and to a lesser degree from the surrounding slopes feeds the lake during summer (Wand et al. 1987). The lake outlet is formed by the deeply incised Pagodroma Gorge that leads into Beaver Lake, an epishelf lake that is hydrologically connected to the ocean underneath Amery Ice Shelf (Fig. 8.6-1). 
Radok Lake Basin was formed by Late Cenozoic glacial erosion, i.e., repeated excavation by the paleoBattye Glacier (Adamson et al. 1997). However, a widespread ice coverage of Amery Oasis seems to have not occurred during the Last Glacial Maximum. This is suggested by the lack of geomorphological evidence for isostatic uplift during the latter half of the Holocene (Adamson et al. 1997). The overdeepening of Radok Lake likely occurred along a tectonically weak zone, the Amery Fault, which runs along the long axis of the lake. The Amery Fault separates Precambrian metamorphic and intrusive rocks to the west from Permian Radok Conglomerate to the south and Permo-Triassic sandstones to the east of the lake (McLoughlin and Drinnan 1997; Mikhalsky et al. 2001).

Despite the extraordinary setting and status of Radok Lake, little is known of its limnological and sedimentological characteristics. The study of its limnology would contribute significantly to a better understanding of the hydrologic conditions in deep, high polar lakes, of which only a few exist. The investigation of sediment sequences from Radok Lake will indicate, if these records can be used for the reconstruction of past climatic and environmental changes in Amery Oasis. Water samples and sediment sequences were collected from Radok Lake during an expedition in austral summer 2001/2002. Water samples were analysed and the sediment sequences described and biogeochemically characterised.

\section{Materials and Methods}

Subsequent to bathymetrical measurements, water sampling and analyses were carried out at locations Lz1007 and Lz1012 (Fig. 8.6-2). At both locations a water sampler (UWITEC Co., Austria) was used to sample the water column along a vertical profile. Immediately after the recovery of a water sample, conductivity (WTW LF 197 probe), $\mathrm{pH}$ (WTW pH 197 probe), oxygen content, and temperature (WTW Oxi 196 probe) were measured. Aliquots of $60 \mathrm{ml}$ were filtered through a $0.45 \mu \mathrm{m}$ glass fibre filter for laboratory analyses of major cations (ICP-OES, Perkin-Elmer Co.) and anions (ion chromatograph,Dionex Co.). 11 of each water sample was filtered through a $0.45 \mu \mathrm{m}$ cellulose acetate filter, dried, and stored in a plastic container for identification of diatom communities.

Sediment coring was carried out using gravity and piston corers (UWITEC Co.; Melles et al. 1994; Wagner 2003) at sites Lz1007, Lz1010, and Lz1012 (Fig. 8.6-2) through holes in the lake ice-cover. After core opening and documentation in the laboratory, subsamples were taken at 1-2 cm intervals, freeze-dried, and water contents (\%) determined. Subsamples were ground and homogenized to measure total carbon (TC), total nitrogen (TN), and total sulphur (TS) using an Elementar III (VARIO Co.) analyser.

Five samples from cores Lz1007 $(2 \mathrm{~cm}$ and $151 \mathrm{~cm})$ and Lz1010 $(2 \mathrm{~cm}, 101 \mathrm{~cm}$, and $302 \mathrm{~cm})$ were used for diatom analyses. Preparation of diatom slides followed the procedure described in Cremer et al. (2001) for identification and enumeration at 1 000x magnification on an Olympus BX51 microscope with differential interference contrast. A Nikon Coolpix 990 digital camera was used for photographic documentation of diatom taxa.

Results and Discussion

Limnology

In early January 2002, Radok Lake was covered by ca. $3 \mathrm{~m}$ of ice and up to $1 \mathrm{~m}$ of snow. In late January 2002, the lake ice-cover was observed to be melting at the tip of the northeastern branch. The melt seemed to be of minor importance compared to earlier years (Adamson et al. 1997), due to thick snow accumulation and consequent increased albedo during early summer 2001/2002. Snow cover was noticably reduced in early February 2002 and lake ice became exposed, particularly in the central areas of the lake.

Water sample analyses from Lz1007 (74 m water depth) and Lz1012 (357 m water depth) performed on January 14 and 272002 revealed only minor variations throughout the water column (Table 8.6-1).Notably low ion concentrations, conductivity, and $\mathrm{pH}$ measured at $4 \mathrm{~m}$ depth from location Lz1007 can be explained by the influence of melted snow penetrating through the ice hole into the water column (Table 8.6-1). Apart from this sample, the water columns from both the northeastern branch and the front of Battye Glacier are characterised by low ion concentrations, low conductivities (ca. $160 \mu \mathrm{S} \mathrm{cm}^{-1}$ ), and a pH between 7.5 and 7.9 (see also Wand 
et al. 1987). Only the bottom water sample at $357 \mathrm{~m}$ depth has a $\mathrm{pH}$ of 8.3 (Table 8.6-1).A slight increase of temperature with increasing water depth is observed at both locations.A maximum temperature of $1.6^{\circ} \mathrm{C}$ was measured from the bottom water of the northeastern branch. Variations in oxygen content (11.4 to $14.2 \mathrm{mg}^{-1}$ ) can be attributed to temperature changes, however, oxygen saturation amounts to more than $85 \%$ throughout the water columns at both locations.

Minor variations in the vertical hydrological profiles reveal that Radok Lake was completely mixed in January 2002 and confirm earlier observations (Wand et al. 1987; Adamson et al. 1997). Low conductivities and ion concentrations are caused by the supply of ion depleted meltwater from Battye Glacier and the surrounding slopes. Ion depleted waters in general are poor in nutrients and thus hamper lake primary productivity. Productivity in Antarctic lakes is additionally constrained by ice and snow cover, particularly if the ice and snow cover persist during summer.Although photosynthesis can take place when ice and snow cover permit less than $1 \%$ of incident light to penetrate through (McMinn et al. 2000; Hawes et al. 2001), reduced light penetration into the water column confines the occurrence of photo-autotrophic algae and microbial organisms. They form the major part of primary production in Antarctic lakes. The short growing season in combination with low nutrient availability may explain the planktonic diatom absence in Radok Lake. This observation agrees with other studies of Antarctic lakes (e.g.,Hodgson et al. 2001; Laybourn-Parry et al. 2001; Sabbe et al. 2003; Verleyen et al. 2003).

The low productivity in Radok Lake was also reflected in the oxygen gradients throughout the water column. Neither a horizon of enhanced primary productivity indicated by oxygen supersaturation nor a horizon of oxygen depleted bottom waters, caused by enhanced bacterial decomposition of organic matter, was observed in the northeastern branch or in front of Battye Glacier. Continued oxygen saturation throughout the water column even after at least 10-12 months of ice coverage confirmed that Radok Lake is ultra-oligotrophic today and has reduced photo-autotrophic primary production.

\section{Sedimentary Records}

The sediment records obtained from the three locations Lz1007, Lz1010, and Lz1012 in Radok Lake (Fig. 8.6-2) indicate distinct local and stratigraphic differences. However, interpretation of the latter is hampered by lack of chronological data. Radiocarbon dating of the sediments was excluded due to the presence of finely disseminated coal fragments, which were mainly derived from coal-bearing Permo-Triassic sandstones to the east of the lake and would have produced erroneous ages. Dating via optically stimulated luminescence (OSL/ IRSL) was rejected, due to the strong probability of incomplete bleaching of feldspars and quartz grains due to the short travel distances of lateral meltwater inflows or subglacial sediment supply from Battye Glacier (see also Krause et al. 1997). Finally, dating of the surface sediments via the ${ }^{210} \mathrm{~Pb}$ method was not applicable, because surface sediments at Beaver Lake nearby (Fig. 8.6-1) revealed that recent atmospheric input of ${ }^{210} \mathrm{~Pb}$ into the lake is not sufficient to obtain reliable ages.

\section{Lz1007}

The $202 \mathrm{~cm}$ long sediment sequence Lz1007 from a water depth of $74 \mathrm{~m}$ in the northeastern branch of Radok Lake exhibits decreasing grain sizes from the bottom to the top (Fig. 8.6-3). The core base is overconsolidated, has a stiff consistency, is coarse sand dominated, and contains high amounts of gravel and pebbles, yet this occurrence is distinctly reduced between 125 and $58 \mathrm{~cm}$ depth. Above that depth, a laminated fine mud occurs, with thin turbidites in the topmost $30 \mathrm{~cm}$. The general fining upward is correlated with an increase in water content and a decline of sediment consolidation. Coal particles are common throughout the sequence, particularly in the unlaminated sediments below $58 \mathrm{~cm}$ depth. Other organic remains were not found, except for the sediment surface, where a 1-2 cm thick layer of water mosses was growing. Diatoms are absent at $151 \mathrm{~cm}$ depth, however, a benthic diatom assemblage, mainly composed of Muelleria peraustralis, Stauroneis anceps, and Psammothidium spp., is preserved at $2 \mathrm{~cm}$ depth (Table 8.6-2; Fig. 8.6-4). Relatively high amounts of TC between 0.7 and $7.0 \%$ and low amounts of TN and TS throughout the sediment sequence are mainly due to the coal particles in the sediment, likely originating from the coal bearing sandstones to the east of the lake. 
Sediment sequence Lz1007 documents the deglaciation of the northeastern branch of Radok Lake. The deposition of overconsolidated coarse and stiff sediments at the basis can be related to the latest stage of glaciation or to the early deglaciation. The fining upward reflects gradual glacier retreat. The onset of deglaciation is uncertain, but probably simultaneous with local ice retreat in Amery Oasis prior to 12 ka b.p. (D. Gore, pers. communication; Wagner et al. in press). Relatively high sedimentation rates during the deglaciation may explain lack of diatoms at $151 \mathrm{~cm}$ depth. Above $58 \mathrm{~cm}$ the glacier had retreated too far to have a direct impact on sediment deposition at the coring site. However, lamination and turbidite layers suggest disturbed sedimentation, with sporadic embanking of sand layers from ice related transport or mass movement processes from the steep slopes in the vicinity of the coring location. A decrease of the $\mathrm{C} / \mathrm{N}$ ratio from ca. 30 at the base to ca. 15 at the sediment surface is likely to be due to higher deposition of autochthonous organic matter in the younger lake history (Fig. 8.6-3). Whereas single coal particles have a $\mathrm{C} / \mathrm{N}$ ratio between 28 and 41, corresponding with the deeper sediments in core Lz1007, autochthonous matter commonly has a $\mathrm{C} / \mathrm{N}$ ratio between 7 and 10 (Meyers and Ishiwatari 1995). The autochthonous organic matter can be formed in situ, e.g., from water mosses. However, it can also originate from shallower parts of the lake and be supplied to the coring site by sediment redeposition. Sediment redeposition is confirmed by the occurrence of benthic diatoms (1.6 valves $\times 10^{6} \mathrm{~g}^{-1}$ dry sediment) at $2 \mathrm{~cm}$ depth in core Lz1007. Most of these diatoms prefer relatively shallow waters (Sabbe et al. 2003) and thus likely originate from lateral parts of the lake. The occurrence of benthic diatoms in contrast to the lacking planktonic diatoms probably is promoted by a direct turnover of the few nutrients, which are released from the sediment surface by bacterial decomposition.

Lz1010

Sediment sequence Lz1010 is $593 \mathrm{~cm}$ in length (Fig. 8.6-3). The base is formed from a stiff diamicton of brown to dark grey colour with low water content and a lack of stratification. Between 530 and $60 \mathrm{~cm}$ follows a thick horizon of mainly silt and clay with sporadic occurrences of coarse sand grains and gravel. The base of this horizon is slightly laminated. The occurrence of all grain sizes, the stiff consistency, and the low water content throughout this sequence suggest deposition as a till or, alternatively, glaciolimnic sediments with ice rafted debris (IRD) supply and without overconsolidation by grounded ice. Its stiff consistency could then be due to a very old age and former overburden by sediments that have become eroded by mass movement. The top $60 \mathrm{~cm}$ of sediment sequence Lz1010 are characterised by mud with fine laminated turbidites, relatively high water content, and dark grey brown to olive brown colour. Coal particles were common throughout the complete sequence, particularly below $60 \mathrm{~cm}$ depth. Other organic remains were not found, except in the surface sediments. Whilst diatoms are absent at depths of 302 and $101 \mathrm{~cm}$, a benthic diatom assemblage (6.0 valves $\times 10^{6} \mathrm{~g}^{-1}$ dry sediment) mainly composed of Muelleria peraustralis, Diadesmis spp., Stauroneis anceps, Amphora veneta, and Psammothidium spp. was identified at a depth of $2 \mathrm{~cm}$ (Table 8.6-2; Fig. 8.6-4). The sediment surface was covered by growing water mosses.

Sediment sequence Lz1010 documents the deglaciation of northern Radok Lake by the up-core decrease in grainsize distribution and consistency. TC and TN values in the glacial or glaciolimnic facies indicate incorporation of coal particles from the sedimentary rocks to the east of the coring location, although to a minor content than recorded at location Lz1007. A relatively higher sediment supply from the Precambrian metamorphic and intrusive rocks to the west of the lake is also recorded in the $\mathrm{C} / \mathrm{N}$ ratio, which is in general lower in core Lz1010. C/N ratios of less than 10 and the occurrence of the benthic diatom assemblage in the surface sediments imply that autochthonous organic matter was particularly contributed in recent times, probably by redeposition of lake edge sediments. This is supported by the occurrence of turbidites in the top 60 $\mathrm{cm}$ of core Lz1010. The diatom assemblage in core Lz1010 is more or less conformable with core Lz1007 except a total diatom abundance four times higher and differences in the relative abundance of Diadesmis spp. and Stauroneis anceps (Table 8.6-2). These differences might be attributable to different geological and bathymetrical situations or different amounts of sediment redeposition at both sites. Overall, the benthic diatom flora in surface sediment samples from Radok Lake consists of 14 taxa, of which three taxa are endemic to Antarctic inland waters (Table 8.6-2, Fig. 8.6-4). Diatom diversity is relatively low compared, for example, to Larsemann Hills and Rauer Islands (Sabbe et al. 2003) or from lake environments of the maritime and subAntarctic (e.g., Jones 1996, and references therein). However, recently relatively broad and unprecise taxonomic 
concepts might lead to underestimation of the number of diatom taxa and the grade of endemism in Antarctic inland waters (Jones 1996; Sabbe et al. 2003).

Lz1012

The $25 \mathrm{~cm}$ long sediment sequence Lz1012 is made up of alternating horizons of sand, silt, and clay of different colours (Fig. 8.6-3). Single layers show a gradual upward fining of grain size, which is typical for turbidites. The thickest of these turbidites occurs between 21 and $15 \mathrm{~cm}$ depth. The overall consistency of the sediment is soft and the water content is similar to surface sediments at the other coring locations. Coal particles and other organic remains were not observed macroscopically, although TC, TN, and TS abundances indicate their presence (Fig. 8.6-3).

Because coring location Lz1012 is in front of Battye Glacier and in the deepest part of the lake, sediment supply from the glacier and from the surrounding subaquatic slopes can be assumed. Dropstones were not observed, indicating a relatively stable glacier front in recent times, low sediment supply from the glacier, or both. Sediment lamination is similar to the surface sediments from the northern and northeastern branches. The turbidites indicate unstable sedimentation conditions with accumulation of sediments from the slopes above. This is confirmed by $\mathrm{C} / \mathrm{N}$ ratios, which encompass a similar range as the surface sediments at the other two locations.

\section{Conclusions}

By the study of the recent hydrological conditions and the sedimentary records of Radok Lake the following conclusions can be drawn concerning the recent and historical conditions in the lake.

High oxygen saturation, low ion concentrations, and the lack of planktonic diatoms throughout the water column indicate that Radok Lake is ultra-oligotrophic today and completely mixed even after at least 10-12 months of ice coverage.

The sedimentary records of Radok Lake document glaciation and deglaciation of the basin in historical times and the transition to the recent postglacial limnic setting. Geological differences in the catchment and their influences on sediment supply are reflected in the $\mathrm{C} / \mathrm{N}$ ratio, which also indicates a recent increase in lake primary productivity.

The lithology of the uppermost sediments and the occurrence of benthic diatom assemblages in relatively deep waters suggest unstable subaquatic slopes and sediment redeposition. This, along with the lack of applicable dating methods make sediment records from Radok Lake unsuitable for detailed paleoenvironmental reconstructions.

Acknowledgments: The project was initiated by Martin Melles (University Leipzig, Germany) and Damian Gore (Macquarie University, Sydney). It was funded by the Deutsche Forschungsgemeinschaft (Grant Me 1169/4) and the Australian Antarctic Science Advisory Committee (ASAC Grant 1071). Special thanks are due to Martin Klug, Gerald Müller, Andy Cianchi, Margie Jenkin and Rob Ferguson for their assistance in the field. The data of the water contents and ion concentrations were provided by Nadja Hultzsch (Alfred Wegener Institute,Potsdam,Germany).The manuscript benefitted from comments of Damian Gore, Martin Melles, and an anonymous reviewer.

\section{References}

Adamson DA, Mabin MCG, Luly JG (1997) Holocene isostasy and late Cenozoic development of landforms including Beaver and Radok Lake basins in the Amery Oasis, Prince Charles Mountains, Antarctica. Antarct Sci 9:299-306

Cremer H,Wagner B,Melles M,Hubberten H-W (2001) The Holocene environmental development of Raffles S $\varnothing$, East Greenland: inferences from a 10000 year diatom record. J Paleolim 26:67-87

Cremer H, Gore D, Hultzsch N, Melles M, Wagner B (2004) The diatom flora and limnology of lakes in the Amery Oasis, East Antarctica. Polar Biol 27:513-531 
Doran PT, Wharton Jr RA, Lyons WB (1994) Paleolimnology of the McMurdo Dry Valleys, Antarctica. J Paleolim 10:85-114

Hawes I,Moorhead D, Sutherland D, Schmeling J, Schwarz AM (2001) Benthic primary production in two perennially ice-covered Antarctic lakes: patterns of biomass accumulation with a model of community metabolism. Antarct Sci 13:18-27

Hendy CH (2000) Late Quaternary Lakes in the McMurdo Sound Region of Antarctica. Geogr Ann 82:411-432

Hodgson DA, Noon PE, Vyverman W, Bryant CL, Gore DB, Appleby P, Gilmour M,Verleyen E, Sabbe K, EllisEvans JC,Wood PB (2001) Were the Larsemann Hills ice-free through the Last Glacial Maximum? Antarct Sci 13:440-454

Jones VJ (1996) The diversity, distribution and ecology of diatoms from Antarctic inland waters. Biodiv Conserv 5:1433-1449

Krause WE, Krbetschek MR, Stolz W (1997) Dating of Quatarnary lake sediments from the Schirmacher Oasis (East Antarctica) by infra-red stimulated luminiscence (IRSL) detected at the wavelength of $560 \mathrm{~nm}$. Quat Sci Rev 16:387-392

Laybourn-Parry J,Quayle WC,Henshaw T,Ruddell A,Marchnat HJ (2001) Life on the edge: the plankton and chemistry of Beaver Lake, an ultra-oligotrophic epishelf lake,Antarctica. Freshw Biol 46:1205-1217

McLoughlin S, Drinnan AN (1997) Fluvial sedimentology and revised stratigraphy of the Triassic Flagstone Bench Formation, northern Prince Charles Mountains, East Antarctica. Geol Mag 134:781-806

McMinn A, Bleakley N, Steinburner K, Roberts D, Trenerry L (2000) Effect of permanent sea ice cover and different nutrient regimes on the phytoplankton succession of fjords of the Vestfold Hills Oasis, eastern Antarctica. J Plankt Res 22:287-303

Melles M, Kulbe T, Overduin PP, Verkulich S (1994) The expedition Bunger Oasis 1993/94 of the AWI Research Unit Potsdam. In: Melles M (ed) The expeditions Norilsk/Taymyr 1993 and Bunger Oasis 1993/94 of the AWI Research Unit Potsdam, Reports Polar Res 148.AlfredWegener Institute for Polar and Marine Research, Bremerhaven, pp 27-80

Melles M, Kulbe T, Verkulich SR, Pushina ZV, Hubberten H-W (1997) Late Pleistocene and Holocene environmental history of Bunger Hills, East Antarctica, as revealed by fresh-water and epishelf lake sediments. In: Ricci CA (ed) The Antarctic region: geological evolution and processes. Terra Antartica Publication, Siena, pp 809-820

Meyers PA, Ishiwatari R (1995) Organic matter accumulation records in lake sediments. In: Lerman A, Imboden D, Gat J (eds) Physics and Chemistry of Lakes. Springer, Berlin Heidelberg New York, pp 279-328

Mikhalsky EV, Sheraton J, Laiba AA, et al. (2001) Geology of the Prince Charles Mountains, Antarctica. AGSO, Geoscience Australia, Canberra

Quayle WC, Peck LS, Paet H, Ellis-Evans JC, Harrigan PR (2002) Extreme responses to climate change in Antarctic lakes. Science 295:645-650

Roberts D, van Ommen TD, McMinn A, Morgan V, Roberts JL (2001) Late-Holocene East Antarctic climate trends from ice-core and lake-sediment proxies. The Holocene 11:117-120

Sabbe K, Verleyen E, Hodgson DA, Vanhoutte K, Vyermann W (2003) Benthic diatom flora of freshwater and saline lakes in the Larsemann Hills and Rauer Islands, East Antarctica. Antarct Sci 15:227-248

Spaulding SA, McKnight DM (1999) Diatoms as indicators of environmental change in Antarctic freshwaters. In: Stoermer EF, Smol JP (eds) The diatoms: applications for the environmental and earth sciences. Cambridge University Press, Cambridge, pp 245-263

Verleyen E, Hodgson DA, Vyvermann W, Roberts D, McMinn A, Vanhoutte K, Sabbe K (2003) Modelling diatom responses to climate induced fluctuations in the moisture balance in continental Antarctic lakes. J Paleolim 30:195-215

Wagner B (2003) The expeditions Amery Oasis, East Antarctica, 2001/02 and Taylor Valley, southern Victoria Land, 2002. Reports on Polar and Marine Research 460, Bremerhaven

Wagner B, Cremer H, Hultzsch N, Gore DB, Melles M (in press) Late Pleistocene and Holocene history of Lake Terrasovoje, Amery Oasis, East Antarctica, and its climatic and environmental implications. J Paleolim

Wand U, Hermichen W-D, Höfling R, Mühle K, Klokov VD, Ufimcev AV (1987) Stable isotope and hydrogeochemical studies of Beaver Lake and Lake Radok, MacRobertson Land, East Antarctica. In: Wand U, Strauch G (eds): Proc $4^{\text {th }}$ Working Meeting, Isotopes in Nature, Leipzig, pp 647-659 


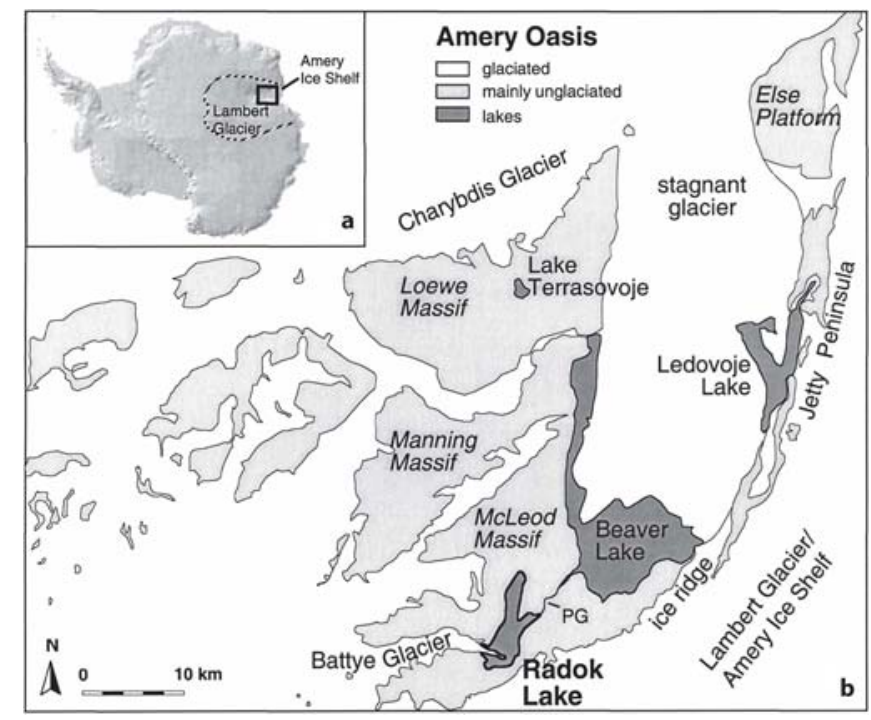

Fig. 8.6-1.

a Map of Antarctica showing the location of Amery Oasis at the margin of the Lambert Glacier-Amery Ice Shelf drainage sys-tem (dashed line). b Location of Radok Lake in Amery Oasis

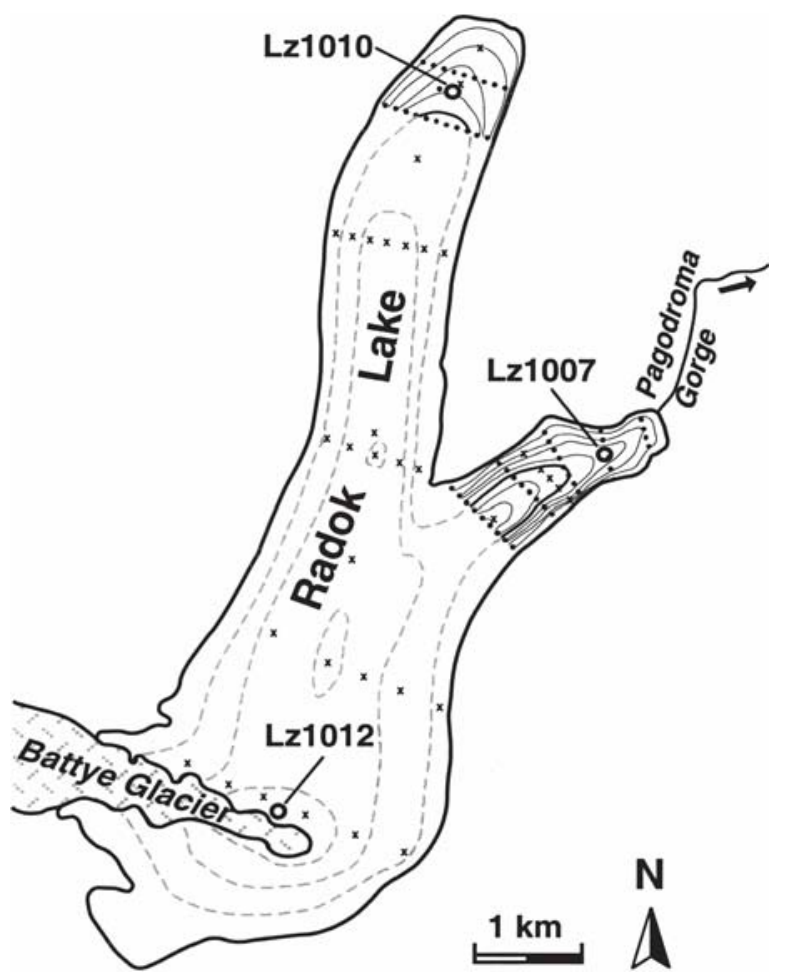

Fig. 8.6-2. Bathymetry of Radok Lake, based on single spot measure-ments carried out in 2001/2002 (dots) and during an earlier expedi-tion (crosses; Adamson et al. 1997). Continuous contour lines are given in $20 \mathrm{~m}$ intervals, dashed lines in $100 \mathrm{~m}$ intervals. Open circles indi-cate the location of water profiles and sedimentary records obtained during the expedition 2001/2002 

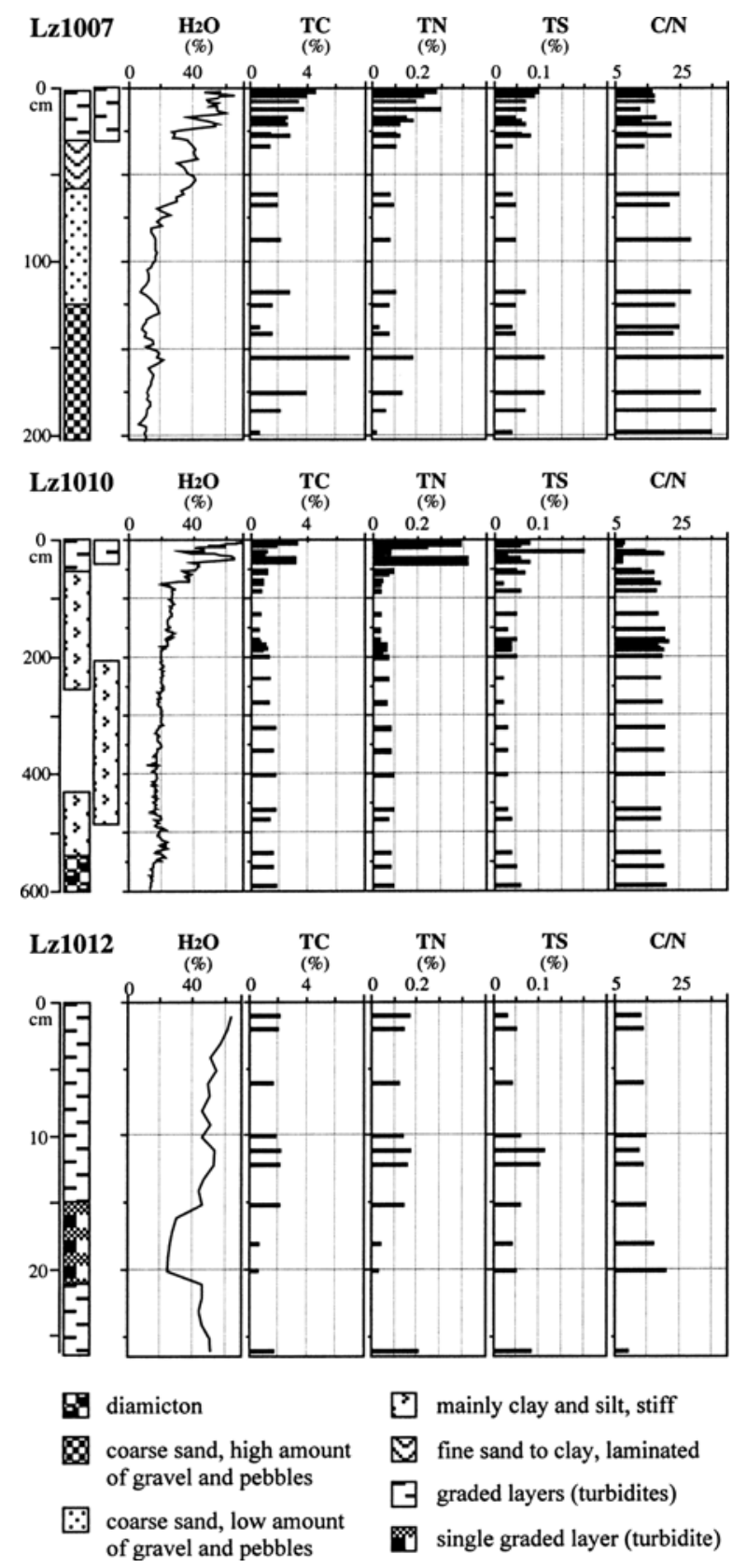

Fig. 8.6-3.

Lithology, water content, and biogeochemical parameters of the sediment sequences obtained at coring locations Lz1007, Lz1010, and Lz1012 in Radok Lake. Note different scales of y-axis 


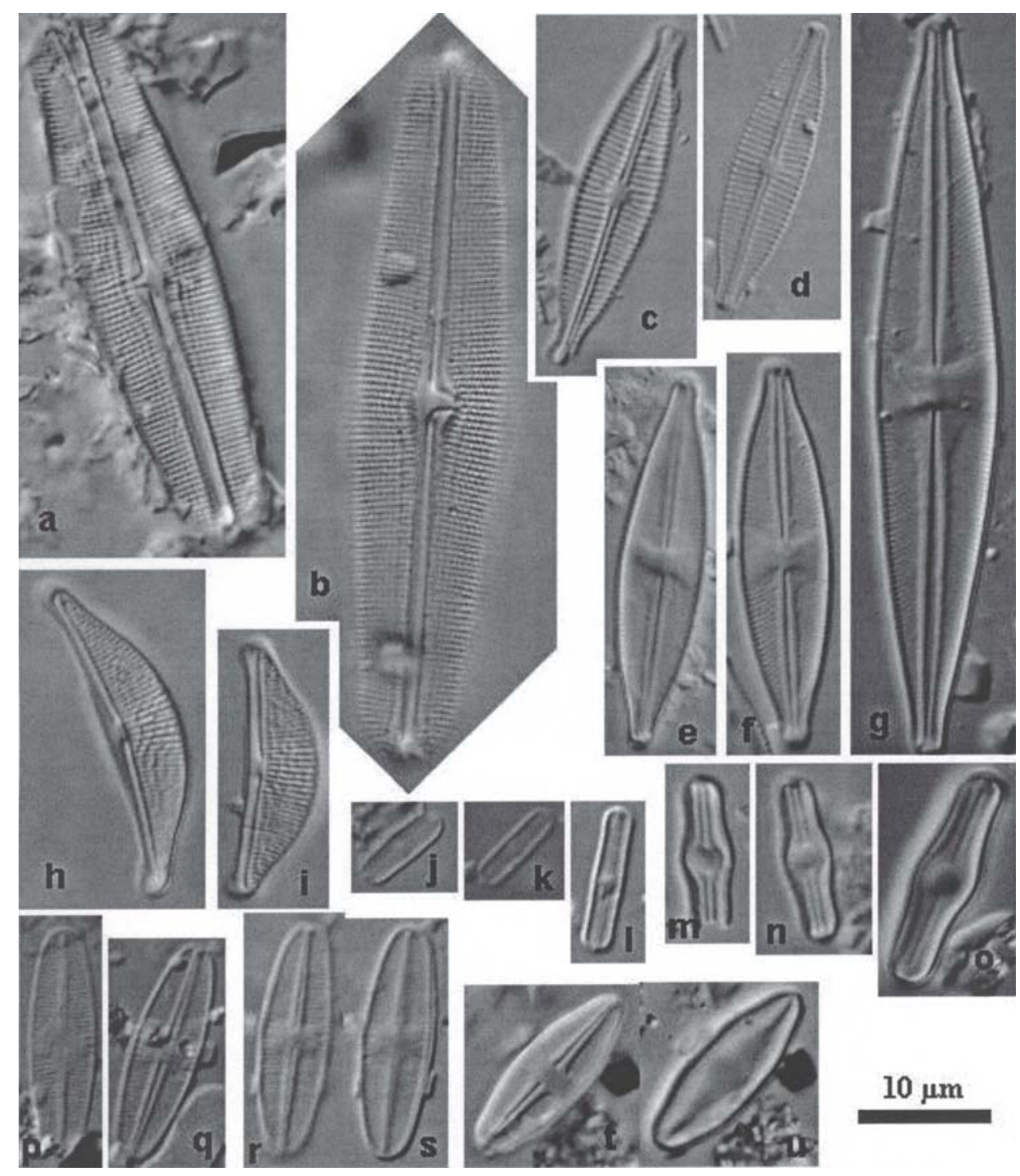

Fig. 8.6-4.

Light micrographs of diatoms identified in surface sediments from Radok Lake. All photos in valve view. a, b Muelleria peraustralis (West et West) Spaulding et Stoermer; c, d Craticula cf. molesta (Krasske) Lange-Bertalot et Willmann; e-g Stauroneis anceps Ehrenberg; h, i Amphora veneta Kützing; j, k Diadesmis sp. 1; 1 Diadesmis cf. ingeae Van de Vijver; m-o Diadesmis cf. perpusilla (Grunow) Mann; p-s Psammothidium metakryophilum (Lange-Bertalot et Schmidt) Sabbe; t, u Psammothidium stauroneioides (Manguin) Bukhtiyarova

Table 8.6-1.

Hydrological and geochemical data from water profiles at locations LZ1007 (74 m water depth) and Lz1012 (357 m water depth) in Radok Lake (Fig. 8.6-2). major ciation and anion concentrations were only measured at location LZ1007

Table. 8.6-2.

Relative abundance (\%) of diatom taxa in surface sediments ( $2 \mathrm{~cm}$ depth) of Radok Lake. Detailed morphological and morphometric information on the taxa is available in Cremer et al. (2004) see: DOI:10.1594/PANGAEA.605211 